\title{
Reinforcement of Civil Societies in Democracy
}

\author{
Syafhendry \\ Lecturer Islamic University Of Riau \\ Pekanbaru, Indonesia \\ Email: syafhendry.ip@soc.uir.ac
}

\author{
Setyo Utomo \\ Lecturer at Islamic University of Riau \\ Student of Doctoral Program at Padjadjaran University \\ Pekanbaru, Indonesia \\ Email: Setyoutomo993@gmail.com
}

\begin{abstract}
Abstrak-The reformation wave 98 has given fresh air for the growth of democracy in Indonesia. The collapse of the hegemonic New Order power has given rise to public pressure to bring democracy into state practice. In the democratization system, the existence of civil society becomes a necessity to control the power of the state as well as the process of bargaining position in fighting for the aspirations and interests of society. Therefore, state power is not absolute and move forward to the interests of public aspirations. In civil society requires critical society, rational thinking and can appreciate differences. At the same time, the state must also open up a space of freedom for the community to assemble and associate in order to strike for that interest. With the result that public participation in coloring the policy process can be realized.
\end{abstract}

Keyword: Reformation, Civil Societies, Democracy

\section{INTRODUCTION}

In an atmosphere of globalization, democracy as a modern political school more gained a place in the life of the state. In fact, democracy has become a globalized phenomenon that is happened in many countries of the world which every country of the world have created a democracy as a choice of a way in the process of nation and state. It is more caused by the factor of a democratic side which puts the society as the holder of the highest sovereignty in the life of the state because one of the absolute characteristics in the democratic state is the position of the society as the government own (people own government). This is also true in democratic Indonesia where the highest sovereignty is in the hands of the society.

Democracy as a state system provides greater opportunities for civil societies to participate in coloring the process of policymaking in the state process. So the democratization is a necessity for the creation of civil societies because it is the mechanism of civil society itself.

Nowadays, in this era of democracy, the Indonesian nation has wider opportunities to develop civil society groups in order to more establish. In openness era and democratization, civil society has a wide opportunity to participate in the process of policymaking in favor of the public interest.
The atmosphere of democratization in Indonesia is marked by the emergence of a reform process that is more familiar with reform 98 which requires the change of long social arrangement deemed undemocratic and replaced by new social consensus demanding more openness and more genuine community involvement in the state process. Reformation really become a public aspiration that cannot be avoided anymore. The spirit of the reformation is based on the values of the transformation toward a more democratic one. This transformation background is factored by the strong of the state during the New Order era which the state is very strong and the power of the society is very weakly because restricted by the state.

In the result, it is needed the strategy and tactics as an effort to increase the strength of civil societies become has a strong position in the political process to determine the direction of state policy.

According to Dewanta's statement about this society's position (1996: 276), is not in the sense of undermining or sacrificing the state. This powerful state has a sense that can commit their functions effectively by corroborating the community's role on the other side of the policy formulation process.

In this democratic system, society is expected not only to be the object of policy, but the power of civil society is able to determine everything related to interests, whether in the field of economy, politics, education and other social interests. So the societies really become the subject that is able to take a real part in the development process of democratic are.

\section{DISCUSSION}

A. The Relationship Between Civil Societies And Democracy

Civil societies are a citizen who acts collectively to achieve a common goal that focuses on the public interest, without having to seize power. So the main prerequisite in civil societies is the existence of equality that rests on the great soul to accept every difference. Civil societies and democracy are two variables that affect each other's 
existence. Where if the civil society is strong then democracy, it will grow and develop well. Hence, civil society is the right habitat for the growth of democracy.

Democracy which does not provide space for civil societies strengthening will bring about procedural democracy. In addition, it will flop down from substantive democracy objectives which power is operated by societies for the purposes of people's prosperity. Civil societies should pay attention to focus on important sectors of the country such as economic development, political process, law enforcement to education and culture.

Democracy is an alternative system for the regulation of the state power of government that is principled on the view that power is from, by, and for society's interest. Democracy has advantages compared other systems such as autocracy and oligarchy, for example, is to power regulatory systems. This is because democracy has some basic essences as identified by Wickell (2014) covering 13 principal values like (1) citizen participation, (2) equality, (3) political tolerance, (4) accountability, (5) transparency (8) the existence of a control over the abuse of power, (9) acceptance of election results, (10) enforcement / guarantee of human rights, (8) (11) the consistent application of multi-party systems, (12) upholding the principles of the rule of law and (13) guarantees for citizens to get protection from the practice of power abuse.

Besides the advantages of democracy also has several weaknesses. The weaknesses include: First, democracy is more promising and does not guarantee the birth of a just ruler and policy. So many examples in many developing countries emerge liberal policies that are not pro-poor (propoor people). Second, the practice of democracy is often plowed and easily manipulated by groups or forces of hegemony in society so that the resulting policy is often biased and tends to prioritize the interests of hegemonic groups. Third, democracy in practice is difficult to find a model appropriate to the history and culture of the people who adopt the democratic system.

However, besides the advantage of democracy also has several weakness. The weakness includes first, democracy is more giving promising and does not guarantee appeared ruler and policy justly. So many examples in many developing countries emerge liberal policies that are not pro-poor (propoor people). Second, the practice of democracy is often plowed and easily manipulated by groups or forces of hegemony in society so that the resulting policy is often biased and tends to prioritize the interests of hegemonic groups. Third, democracy in practice is difficult to find a model appropriate to the history and culture of the people who adopt the democratic system.

According to Dahl (in Silaen, 2000: 8), civil societies are characterized by the characteristics of society: the highest level of political participation of the community; the opening of vast and free public spaces and the formation of critical societies. From Silaen's opinion above, civil societies require an active process of community groups, whether religious groups of organizations, ideological ties, or professional associations and other critical groups in the political decision making process. At the same time, the government has a responsibility to the society by opening up public space for the community to associate and union in order to achieve its interests.

In the context of democratization in Indonesia, the potential for the inception of the power of civil societies have actually existed in societies. The larger number of community organizations both general and religious organizations such as NU and Muhammadiyah can be an effective civil society strength to control the path of moneter. As the strength of civil societies, the existence of mass organizations such as NU and Muhammadiyah can play two roles as well as efforts to influence policy. That is, first by opening the members of religion's mindset to more aware of their rights, thus constructed a critical attitude in the state process. Second, at the same time, NU and Muhammadiyah can influence policy directly, either through diplomacy efforts to provide input to the government and through pressure force that can influence the state policy in accordance with public aspirations.

According to Silaen about forming a critical society, (2000: 8) can be achieved through the process of enlightenment by transforming the modern societies into a more modern, national, universal, emphasis on achievement. So, is needed new values that enable the community to think critically and independently, including in freedom, the principle of the unity, independent attitude and toleration. In order to transform these new values to the community, according to Lipset (in Silaen 2000: 9) can be pursued through education, with supporting instruments like urbanization (induced industrialization); literacy, pers, and economic development.

Besides through education as in Lipset's view above, the process of enlightenment of society as an effort to build civil societies in Indonesia can also be done through the transformation values and religious principles in favor of the spirit of justice, openness, the spirit of tolerance that is in line with the principles in civil societies. The process of enlightenment of societies in religious society as in Indonesia is very relevant if the transformation of knowledge is done through education and religious transformation. Because religious doctrine very determines the behavior of mankind in the process of attitudes formation and thinking framework. As in Islamic doctrine both in individuals and societies are emphasized the value of justice (ta'addul), the spirit of freedom (al hurriyah), tolerance (tasammuh) which all are 
breathless in supporting the growth of civil societies to create just and egalitarian societies

\section{B. The Relationship Between Country And Civil Societies}

The relationship between state and civil societies can be constructed that civil societies can act as a counterweight to the state. The existence of civil societies are expected to control state power, so the state does not present itself as an absolute power.

The experts have different views in looking at the relationship between state and civil societies that sometimes contradict to another. In this case, Kuntowijoyo (1996: 29) mentions, at least there are four opinions regarding the relationship between countries and the civil society; first, according to Hegel the settlement of the conflict in the societies to achieve freedom and independence are just only as dilution without having country, second Karl Marx thinks that the existence of the country is no more as a parasite, because the state is used as a tool of the presidential elite of the ruler. So that Marx's Church dreamed of classless societies, it can only be done by the abolition of the state. Third, the more comprehensive view is said by Antonio Gramsci, who view that the state as political and societal societies as civil societies, a state of coercion, a dominance of liberation while society represents a cultural ideology, and consensus; fourth, a view that sees the interfacial functionality of citizens in the countries. Society is in the opposite conflict of interests, between personal interests and general, individual interests with society and between a matter of fact and consciousness. So, this existence gives monitoring and regulation through a mechanism of law. From various opinions of experts above, Hegel saw that the existence of the state is a necessity for a society. Because it is impossible that there are no referees who control the different interests of individuals and communities. Where the interests of each other are sometimes opposite. But Gramsci's attention here is not enough to give a sufficient portion of the negative side of power that can be done by the state. Power is not value-free, even a condition with an interest if it is not balanced with sufficient control of society.

Different views are done by Marx who sees a country with a priori. In Marx's view, the existence of the state only gave inception the problem of injustice with the existence of classes in society, due to the hegemony of state power. For Marx, the power only takes into account its own interests regardless of the interests of societies. So that the existence of the state in Marx is considered only as a parasite that is more beneficial to the ruling class and does not provide benefits to societies.

According, to Antonio Gramsci's, founded the relevance to see the existence of the state and societies more fully. In
Gramsci's view, the state is not a single subject that is free to set its policies without regard to public aspirations and interests. The state has the authority to force the societies to obey with their decision rule. In another side, Gramsci state that in society there is also an ideology and convention that will control and influence state power. Gramsci's view then inspired the inception of civil society in the state process. Where communities have the right and freedom to associate, gather in order to achieve their goals and interests. So the existence of critical societies that are aware of their rights becomes a necessity to limit state directionary. This Gramsci's view finds the relevance of democratization system that gives freedom to the emergence of civil society.

\section{CONCLUSION}

Nowdays, in the current openness era, the atmosphere of democratization must be made as a momentum by the power of civil societies to prevent the domination and hegemony of directional by the state, the civil society must be awakened so that the public really has a critical attitude toward the state. So that power run objectively by promoting the interests and aspirations of the public. We also cannot deny that the role of civil societies is crucial to the quality of democracy of a State. Building a developed government cannot be ignored from the role of civil society as a major part of a good governance system. Democracy as a system demands a vibrant, persistent and pluralist civilization. Thus civil societies have a strategic role in guarding the consolidation of democracy.

\section{REFERENCE}

[1] Dewanta, Awan S, Transformasi Menuju Demokrasi, Dalam: Demokrasi Indonesia Kontemporer, Jakarta: Rajawali Press, 1996.

[2] Wicaksono, Prasetyanto, Hukum Pemungutn Suara. Jakarta: Erlanggadewanta, 1999.

[3] Silaen, Victor, MasyarakatSipildanNegosiasiDemokrasi, Jakarta: Media Indonesia, 2000.

[4] Kuntowijoyo, Agama danDemokratisasi di Indonesia, Dalam: Demokrasi Indonesia Kontemporer, Jakarta: Rajawali Press, 1996. 